\title{
The Influence of Biochar Applications on Modulus of Rupture and Aggregate Stability of the Soil Possessing Crusting Problems
}

\author{
İlknur GÜMÜȘȘ ${ }^{1, *}$ iD \\ Hamza NEGiș'id \\ Cevdet ȘEKER' \\ 'Department of Soil Science and Plant Nutrition, Faculty of Agriculture, University of Selçuk, 42031 Konya, Turkey
}

*Sorumlu yazar e-mail (Corresponding author e-mail): ersoy@selcuk.edu.tr

Geliș tarihi (Received): 12.03.2019

Kabul tarihi (Accepted): 24.06.2019

DOI: 10.21657/topraksu.538580

\begin{abstract}
Protecting and improving the structural properties of soil constitutes the basis for the efficient and sustainable utilization. The purpose of this research was to determine the effects of biochar application with different rates on aggregate stability (AS) and modulus of rupture (MR) of a poorly structured soil under laboratory conditions. During the experiment, 0 (control), 5, 10, 20, and $40 \mathrm{~g} / \mathrm{kg}$ biochar rates were applied to soil and then incubated for 30 days. According to the results, biochar applications significantly affected both modulus of rupture and aggregate stability values of the soil. However 5 , 10,20 and $40 \mathrm{~g} / \mathrm{kg}$ rates of biochar decreased soil modulus of rupture by $9 \%, 26 \%, 42 \%$ and $61 \%$ respectively, increased aggregate stability values by 3\%,27\%, 178\% and 189\% respectively compared with the control. According to finding obtained from the research, biochar which is known as a soil amendment was determined to be a promising agricultural practice for improving soil structure in the short period of time.
\end{abstract}

Key words: Aggregate stability, biochar, soil modulus rupture, soil structure

\section{Kabuk Bağlama Problemli Toprağın Kırılma Değeri ve Agregat Stabilitesi Üzerine Biyokömür Uygulamalarının Etkisi}

Öz

Toprakların strüktürel özelliklerinin korunması ve geliștirilmesi, verimli ve sürdürülebilir kullanımına temel olușturmaktadır. Bu çalıșmanın amacı; farklı dozlarda biyokömür uygulamasının laboratuvar koșullarındaki zayıf strüktürel özelliklere sahip bir toprağın kırılma değeri (KD) ve agregat stabilitesi (AS) değeri üzerine etkilerini belirlemektir. Denemede, toprağa 0 (kontrol), 5, 10, 20 ve $40 \mathrm{~g} / \mathrm{kg}$ oranlarında biyokömür uygulanmıș ve 30 gün boyunca inkübe edilmiștir. Araștırma sonuçlarına göre, biyokömür uygulamaları toprağın hem kırıma değerini hem de agregat stabilitesi değerini önemli ölçüde etkilemiștir. 5, 10, 20 ve 40 g/kg biyokömür dozları toprağın kırılma değerini sırasıyla \%9, \%26, \%42 ve \%61 oranlarında azaltırken, agregat stabilitesi değerini ise sırasıyla \%3, \%27, \%178 ve \%189 oranında artırmıștır. Araștırmadan elde edilen bulgular doğrultusunda; bir toprak düzenleyicisi olarak bilinen biyokömürün toprak yapısını kısa sürede iyileștirme potansiyeline sahip umut verici bir tarımsal uygulama olduğu belirlenmiștir.

Anahtar kelimeler: Agregat stabilitesi, biyokömür, kırıma değeri, toprak yapısı 


\section{INTRODUCTION}

Soil is a leading resource which support mankind, soil and plant food web (Doran and Zeiss, 2000). Irrational agricultural practices threaten increasingly soil quality, thereby decreasing then extent of organic matter into the soil and plant productivity (Verhulst et al., 2010; Martinez-Blanco et al., 2011). Soil degradation seems a crucial difficulty in Mediterranean areas due to anthropogenic activities accompanied with continuous drought periods and irregularly intense precipitation (García-Ruiz et al., 2011; Hueso-González et al., 2014; Rodrigo-Comino et al., 2016, 2017). Soil structural toll is the backbone of soil wreckage (Chan et al., 2003), and soil physical degradation in agricultural land is attributed to decreasing of soil organic matter due to being cultivated excessively (Grandy et al., 2002). Intensified agricultural can result in decreased soil organic matter content, thereby decreasing aggregate stability and occasioning increasingly damage of erosion (Annabi et al., 2011). The depletion of soil organic matter get along with decreasing in soil pores and wet aggregate stability (Șeker and Karakaplan, 1999). Several study stated that soil structure markedly affected crop yield, root penetration, nutrient cycling, soil water holding capacity and motion and soil crusting as well as soil erosion (Seker, 2003; Bronick and Lal, 2005; Bal et al., 2012).

Biochar is described as a highly carbon contained material produced by charring organic residues in the vicinity of temperature less than 700 ${ }^{\circ} \mathrm{C}$ (Lehmann et al., 2006; Verheijen et al., 2010). Biochar which contains a resistant organic carbon compound, is produced from pyrolysizing biomass at high temperature ranging from 300 and 1000 under oxygen constrained condition (Verheijen et al., 2010). Previously conducted study showed that employing biochar as soil amendment had a positive effect in mitigating climate variability issues and sustaining soil profitability (Chan et al. 2007) and the aforementioned effects are achieved through $\mathrm{CO}_{2}$ sequestration and enhancing soil properties respectively (Devereux et al, 2012). Applying biochar to soil may raise the extent of organic matter in the soil, specifically water-extractable organic carbon (Lin et al., 2012) and facilitate soil microbial biomass and activities (Lehmann et al., 2011). Additionally, biochar can improve crop growth by enhancing soil chemical properties including retaining nutrient and nutrient accessibility, soil physical properties including bulk density, water retention ability and permeability as well as biological features, all of which contribute to scaled up plant production (Glaser et al., 2002; Lehmann and Rondon, 2006; Yamato et al., 2006; Asai et al., 2009). Biochar was stated to have the capability of improving soil feature and plant production; nevetheless, little is surfaced on how it affects soil structural properties (Devereux et al., 2012). A little is known about specified processes by which biochar affects water holding capacity, soil macro-aggregate, and stability (Sohi et al., 2009). We hypothesized that biochar addition would affect porosity, and thereby enhancing soil water holding capacity due to direct pore found within biochar, formed pores between biochar and soil aggregates, as well as persistent soil pores induced by increased aggregate stability. Several study has reported that biochar can enhance soil physical properties due to its tremendous porous nature, which lead to creation of new soil pores (Downie et al., 2009; Major et al., 2009; Atkinson et al., 2010; Sohi et al., 2010; Verheijen et al., 2010). Modulus of rupture is a method used to measure mechanical resistance of soil crusting (Richards, 1953; Reeve, 1965). High modulus rupture indicate the susceptibility of soil crusting formation after rainfall and irrigation, and this place a hindrance to shoot emergence (Seker and Karakaplan, 1999; Seker, 2003; Negiș et al., 2016). Soil aggregate stability and modulus rupture have a significant role in the sustainability and development of soil structure.

The aim of this research was to evaluate the effects of biochar application to poorly structured soil subjected to and physical degradation by focusing on the soil modulus of rupture and aggregate stability.

\section{MATERIALS AND METHODS}

\section{Study area}

The soil which was employed in this research, was characterised by the weakly aggregate strength, crusting difficulties and inadequate seedling emergency (Bal et al., 2012). The used soil was located at Selçuk University experimental station closer to Konya Sarıcalar-Village in central Anatolia, Turkey and sampled from 0-20 cm 
Table 1 . Some properties of study soil

Çizelge 1. Çalıșma toprağının bazı özellikleri

\begin{tabular}{llll}
\hline Parameters & Values & Parameters & Values \\
\hline Sand $(2-0.05 \mathrm{~mm})(\%)$ & 6.65 & Carbonates $(\%)$ & 11.58 \\
Silt $(0.05-0.002 \mathrm{~mm})(\%)$ & 34.17 & $\mathrm{C}(\%)$ & 1.35 \\
Clay $(<0.002 \mathrm{~mm})(\%)$ & 59.18 & Field capacity $(\%)$ & 35.6 \\
Textural class & $\mathrm{C}$ & Wilting point $(\%)$ & 16.19 \\
$\mathrm{pH}\left(\mathrm{H}_{2} \mathrm{O}, 1: 1\right)$ & 7.96 & Aggregate stability $(\%)$ & 10.83 \\
$\left.\mathrm{EC}\left(\mathrm{H}_{2} \mathrm{O}, 1: 1\right) \mathrm{dS} \mathrm{cm}\right)^{-1}$ & 0.479 & Bulk density $\left(\mathrm{g} \mathrm{cm}^{-3}\right)$ & 1.09 \\
\hline
\end{tabular}

Table 2. Properties of the biochar

Çizelge 2. Biyokömürün özellikleri

\begin{tabular}{ll}
\hline Parameters & Values \\
\hline $\mathrm{PH}\left(\mathrm{H}_{2} \mathrm{O}, 1: 5\right)$ & 10.66 \\
$\mathrm{EC}\left(\mathrm{H}_{2} \mathrm{O}, 1: 5\right) \mathrm{dS} \mathrm{m} \mathrm{m}^{-1}$ & 20.60 \\
$\mathrm{C}(\%)$ & 36.75 \\
$\mathrm{~N}(\%)$ & 1.97 \\
$\mathrm{C} / \mathrm{N}$ & 18.65 \\
\hline
\end{tabular}

depth. This region has the annually rainfall of $379.38 \mathrm{~mm}$, average temperature of $11.5^{\circ} \mathrm{C}$ as well as average evaporation of $1226.4 \mathrm{~mm}$. The applied biochar in the course of this research was supplied from a private company renowned for producing electrical energy from the poultry manure located in Ankara-Beypazarı, Turkey (The process of decomposition of organic substances in very high temperature $\left(350-700^{\circ} \mathrm{C}\right)$ and nonoxygen environment).

Table 1 and Table 2 present the characterisctics of the study soil. The soil texture was classified as clay.

\section{Experimental layout and analysis}

The experiment was triplicate, designed in accordance with a complete randomized plot and carried out in the laboratory environment (22-23 ${ }^{\circ} \mathrm{C} \pm 3$ ) by using a pot trial. The soil specimens taken at the surface $(0-20 \mathrm{~cm})$ were dried at room temperature, ground and sieved by $2-\mathrm{mm}$ sieve, and thereafter mixed homogeneously. Five pots with dimensions of $13.5 \mathrm{~cm} \times 17 \mathrm{~cm}$ were used during the experiment and packed with $2000 \mathrm{~g}$ of soil for each, and applied five level of biochar; control $(0 \mathrm{~kg} / \mathrm{da}), 5-10-20-40 \mathrm{~g} / \mathrm{kg}$ by weight were homogenously blended with the soil and incubated for 30 days. In the course of incubation, soil moisture was brought to field capacity and regular check up was made to maintain the water at this level.

Soil texture was determined by hidrometer method (Gee et al., 1986), field capacity and permanent wilting point were measured using pressure plate (Cassel and Nielsen, 1986), $\mathrm{pH}$ and electric conductivity (EC) 1:2.5 mixture (v/v) of soil and water (Gugino et al., 2009). Organic matter and total nitrogen were determined Dumas combustion method (Leco Corporation, 2003).

Modulus of rupture as an indication of soil crusting was determined by using the method suggested by Reeve (1965) and aggregate stability was determined by immersing the sieves, containing the aggregate samples (between 1 and $2 \mathrm{~mm}$ size), in distilled water up and down oscillating on screens through $55 \mathrm{~mm}$ at 30 strokes min-1 for 5 min (Kemper and Rsenau, 1986).

ANOVA test was employed for analysing the data and treatment means were contrasted at $p<0.05$ through the LSD significant difference test (Minitab, 1991).

\section{RESULTS AND DISCUSSION}

\section{Modulus of rupture (MR)}

The effectiveness of biochar application in improving soil modulus of rupture are given in Figure 1. After the 30 days incubation, the experimental results showed that the soil modulus 
Modulus of rupture $\mathrm{kPa}$

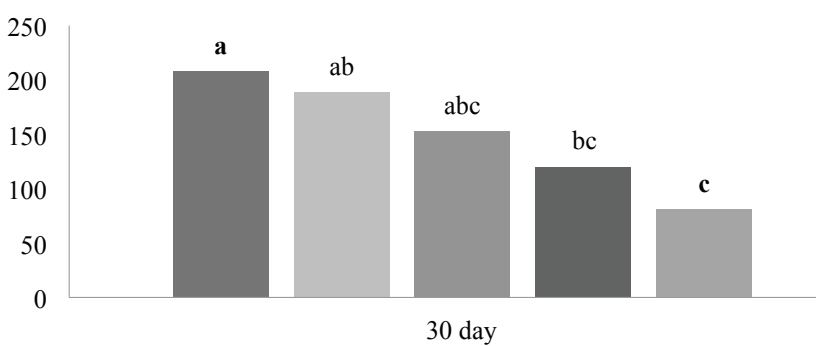

$\square$ control $\square 5 \mathrm{~g} / \mathrm{kg} \square 10 \mathrm{~g} / \mathrm{kg} \square 20 \mathrm{~g} / \mathrm{kg} \square 40 \mathrm{~g} / \mathrm{kg}$

Figure 1. Effects of different application rates of biochar on soil MR

Șekil 1. Biyokömürün farklı uygulama dozlarının toprağın $K D$ üzerine etkisi

of rupture (MR) was significantly decreased in all biochar application rates and the soil MR scaled down with increasing rates of biochar. Application of $5,10,20$ and $40 \mathrm{~g} / \mathrm{kg}$ biochar resulted in decreased soil MR by 9\%, 26\%, 42\% and 61\% respectively compared with the control. Modulus of rupture was determined in the laboratory using prepared soil brick. Modulus of rupture is a valid method used for indicating mechanical resistance of surface crusting despite of different available methods of its determination. High modulus rupture indicate the susceptibility of soil crusting formation after rainfall and irrigation, and this place a hindrance to shoot emergence (Seker and Karakaplan, 1999; Seker, 2003; Negiș et al., 2016). This effect of biochar can be elucidated by the biochar's organic matter content which enhanced the structure of soil in mechanical ways (Seker, 2003; Gümüș and Șeker, 2015, 2017). Modulus of rupture may also be tied to the inhibiting impact of biochar on strengthening bond lies in soil aggregates. Structural stability of soil is tied to the infusion of $\mathrm{OM}$ into the soil (Caravaca et al., 2002; Ferreras et al., 2006), thereby enhancing soil physical properties by applying biochar as an organic matter source (Herath et al., 2013).

\section{Aggregate stability (AS)}

Figure 2 presents the effects of applied biochar on aggregate stability (AS). The results of experiment indicated that applying of biochar to the soil was markedly effective $(P<0.05)$ in improving soil aggregate stability and biochar rates scaled up with rising aggregate stability at large. Application of 5, 10, 20 and $40 \mathrm{~g} / \mathrm{kg}$ biochar resulted in increased AS by 3\%, 27\%, $178 \%$ and $189 \%$ respectively compared with the
Aggregate stability (\%)

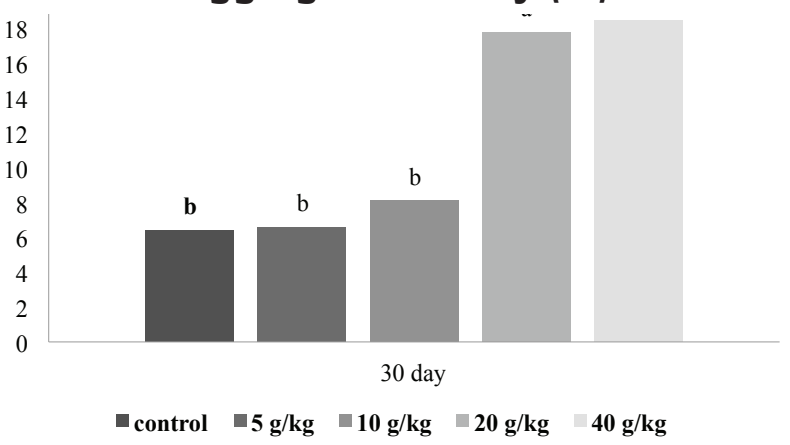

Figure 2. Effects of different application rates of biochar on soil AS.

Șekil 2. Biyokömürün farklı uygulama dozlarının toprağın AS üzerine etkisi

control. The measured soil aggregate stability was found to be low approximately $10.51 \%$ in the course of the study. This was due to a high clay content and newly soil aluvial deposition. It is due to the lack of time to allow aggregation in young alluvial deposits and the wetting-drying and freezing-thawing cycle that encourages aggregation are ineffective due to the low rainfall and the arid-semi-arid climate (Bal et al., 2011; Seker et al., 2014). Aggregate size distribution and durability in soils is an indicator of soil quality (Six et al., 2000). Application of organic matter to soil positively affect the formation of aggregates which is correlated to the pore distribution and hydraulic conductivity, and thus increase the water holding and aeration capacity of soils (liç and Gülser, 2008; Gümüș and Seker, 2015).

Soil AS and organic matter are two leading indication of soil features or profitability the application of biochar enhances aggregate stability, and thus improving soil porosity (Verheijen et al., 2010). Hardie et al. (2013) speculated that biochar application impacted soil porosity through either directly contributing to soil pore, creating accommodation pores, or improving aggregate stability. The increase of aggregate stability could positively scale down the damage of erosion. It is evidenced that physical and bio-chemical characteristics of biochar may take part in binding soil particles into aggregate of different sizes (Sun and Lu, 2014).

\section{CONCLUSION}

According to the experimental findings, it was shown that biochar applications significantly enhance soil structure by increasing aggregate 
stability and lowering soil crusting. After the period of 30 days, the soil modulus of rupture and aggregate stability were enhanced through biochar application and these positive results increased linearly with increasing rate. Therefore, in terms of sustainable agriculture, biochar has proven to be a promising soil amendment for improving sustainably soil quality.

\section{ACKNOWLEDGEMENTS}

I. International Agricultural Science Congress 09-12 May 2018 Van/Turkey is presented as poster presentation.

\section{REFERENCES}

Annabi M, Le Bissonnais $\mathrm{Y}$, Le Villio-Poitrenaud $\mathrm{M}$, and Houot $S$ (2011). Improvement of soil aggregate stability by repeated applications of organic amendments to a cultivated silty loam soil. Agriculture, Ecosystems \& Environment, 144: 382-389.

Asai H, Samson BK, Stephan HM, Songyikhangsuthor K, Inoue Y, Shiraiwa T, Horie T (2009). Biochar amendment techniques for upland rice production in Northern Laos: soil physical properties, leaf SPAD and grain yield. Field Crops Research, 111:81-84.

Atkinson CJ, Fitzgerald JD, Hipps NA (2010). Potential mechanisms for achieving agricultural benefits from biochar application to temperate soils: a review. Plant and Soil, 337:1-18

Bal L, Șeker C, Ersoy Gümüș i (2012). Kaymak tabakası olușumuna fiziko-kimyasal faktörlerin etkileri. Selçuk Tarım ve Gıda Bilimleri Dergisi, 25: 96-103.

Bronick CJ, Lal R (2005). Soil structure and management: a review. Geoderma 124, 3-22.

Cassel D and Nielsen D (1986). Field capacity and available water capacity. Methods of Soil Analysis: Part 1 Physical and Mineralogical Methods, 901-926.

Chan K, Heenan D, So H (2003). Sequestration of carbon and changes in soil quality under conservation tillage on light-textured soils in Australia: a review. Animal Production Science, 43: 325-334.

Chan KY, Van Zwieten EL, Meszaros I, Downie A, Joseph S (2007). Agronomic values of greenwaste biochar as a soil amendment. Australian Journal of Soil Research, 45: 629-634.

Devereux, RC, Sturrock, CJ, Mooney, SJ (2012). The effects of biochar on soil physical properties and winter wheat growth. Earth and Environmental Science Transactions of the Royal Society of Edinburgh, 103: 1318.

Doran JW, Zeiss MR (2000). Soil health and sustainability: managing the biotic component of soil quality. Applied Soil Ecology, 15: 3-11.

Downie A, Crosky A, Munroe P (2009). Physical properties of biochar. In: Lehmann, J., Joseph, S. (Eds.),
Biochar for Environmental Management-Science and Technology. Earthscan, London, pp. 227-249.

Ferreras L, Gomez E, Toresani S, Firpo I, Rotondo, R (2006). Effect of organic amendments on some physical, chemical and biological properties in a horticultural soil. Bioresource Techonology, 97: 635-640.

Garc'ıa-Ruiz JM, Lopez-Moreno Jl, Vicente-Serrano SM, 'Lasanta T, Beguer'ia S (2011). Mediterranean water resources in a global change scenario. Earth-Science Reviews, 105: 121-39.

Gee GW, Bauder JW, Klute A (1986). Particle-size analysis, Methods of soil analysis. Part 1, Physical and Mineralogical Methods, 383-411.

Glaser, B, Lehmann, Jand, Zech, W (2002). “Ameliorating physical and chemical properties of highly weathered soils in the tropics with charcoal - A review". Biology and Fertility of Soils, 35: $219-230$.

Grandy AS, Porter GA, Erich MS (2002). Organic amendment and rotation crop effects on the recovery of soil organic matter and aggregation in potato cropping systems. Soil Science Society of America Journal, 66: 13111319.

Gugino B, Idowu O, Schindelbeck R, Van Es H, MoebiusClune B, Wolfe D, Thies J, Abawi G (2009). Cornell soil health assessment training manual. Edition 2.0, Cornell University, Geneva, NY.

Gümüs I, Seker C (2015). Influence of humic acid applications on modulus of rupture, aggregate stability, electrical conductivity, carbon and nitrogen content of a crusting problem soil. Solid Earth, 6: 1231-1236, https:// doi.org/10.5194/se-6-1231.

Gümüs I, Seker C (2017). Effects of spent mushroom compost application on the physicochemical properties of a degraded soil. Solid Earth, 8: 1153-1160, https://doi. org/10.5194/se-8-1153.

Hardie M, Clothier B, Bound S, Oliver G, Close D (2013). Does biochar influence soil physical properties and soil water availability? Plant and Soil, 376: 347-361.

Herath HMSK, Camps-Arbestain M, Hedley M (2013). Effect of biochar on soil physical properties in two contrasting soils: An Alfisol and an Andisol. Geoderma, 209210: 188-197.

Hueso-González P, Martínez-Murillo JF and Ruiz-Sinoga JD (2014). The impact of organic amendments on forest soil properties under Mediterranean climatic conditions. Land Degradation \& Development, 25: 604-612, doi: 10.1002/ Idr.2296.

İç S, Gülser C (2008). Tütün atığının farklı bünyeli toprakların bazı kimyasal ve fiziksel özelliklerine etkisi. Ondokuz Mayıs Üniversitesi Ziraat Fakültesi Dergisi, 23(2): 104-109.

Kemper WD, Rosenau RC (1986). Aggregate stability and size distribution. In: Methods of Soil analysis, Part 1. Physical and Mineralogical Methods (2nd Edition). Agronomy Monograph, No. 9, pp. 425-442.

LECO Corporation (2003). Truspec carbon/nitrogen 
determinator. Leco Corporation 3000. Lakeview Avenue, St Jeseph, M1 49085-2396, USA.

Lehmann J, Gaunt J, Rondon M (2006). Bio-char sequestration in terrestrial ecosystems, A review. Mitigation and Adaptation Strategies for Global Change, 11: 403-427.

Lehmann J, Rillig MC, Thies J, Masiello CA, Hockaday WC, Crowley D (2011). Biochar effects on soil biotaea review. Soil Biology \& Biochemistry, 43: 1812-1836.

Lin Y, Munroe P, Joseph S, Henderson R (2012) Migration of dissolved organic carbon in biochars and biochar-mineral complexes, Pesqui. Pesquisa Agropecuária Brasileira-PAB, 47: 677-686.

Lindsay WL, Norvell WA (1978) Development of a DTPA soil test for zinc, iron, manganese and copper. Soil Science Society of America Journal, 42:421-428.

Major J, Steiner C, Downie A, Lehmann J (2009). Biochar effects on nutrient leaching. In: Lehmann J, Joseph $S$ (eds) Biochar for Environmental Management. Earthscan Publications Ltd. ISBN: 9781844076581, pp: 271-287.

Martínez-Blanco J, Munoz P, Antón A, Rieradevall J (2011). Assessment of tomato Mediterranean production in openfield and standard multi-tunnel greenhouse, with compost or mineral fertilizers, from an agricultural and environmental standpoint. Journal of Cleaner Production, 19: 985-997.

Minitab C (1991). Minitab reference manual (Release 7.1). State Coll., PA16801, USA.

Negiș H, Șeker C, Gümüși (2016). Dönemsel tarla trafiğinin șeker pancarı tarımında toprak sıkıșmasına etkisi. Selçuk Tarım Bilimleri Dergisi, 3(1): 103-107.

Reeve R (1965). Modulus of rupture, methods of soil analysis. Part 1. Physical and Mineralogical Properties, Including Statistics of Measurement and Sampling, 466-471.

Rodrigo Comino J, Ruiz Sinoga JD, Senciales Gonzàles JM, Guerra-Merchàn A, Seeger M, Ries JB (2016). High variability of soil erosion and hydrological processes in Mediterranean hill- slope vineyards (Montes de Málaga, Spain). Catena, 145: 274-284. doi.org/10.1016/j.catena.2016.06.012.

Rodrigo Comino J, Senciales Gonzjles JM, Ramos MC, Martínez-Casasnovas JA, Lasanta T, Brevik EC, Ruiz Sinoga JD (2017). Understanding soil erosion processes in Mediter- ranean sloping vineyards (Montes de Málaga, Spain). Geoderma, 296: 47-59, https://doi.org/10.1016/j. geoderma.2017.02.021

Ryan J, Estafan G, Rașhid A (2001). Soil and plant analysis laboratory manuel. 2 nd. Ed. ICARDA and NARS, Aleppo, Syria.

Six J, Elliot ET, Paustian K (2000). Soil structure and soil organic matter: a normalized stability index and the effect of mineralogy. Soil Science Society of America Journal, 64: 1042-1049.

Sohi S, Lopez-Capel E, Krull E, Bol R (2009). Biochar, climate change and soil: a review to guide future research. CSIRO Land and Water Science Report, 5:17-31.

Sun F, Lu S (2014). Biochars improve aggregate stability, water retention, and pore-space properties of clayey soil. Journal of Plant Nutrition and Soil Science, 177 (1): 26-33.

Seker C (2003). Effects of selected amendments on soil properties and emergence of wheat seedlings. Canadian Journal of Soil Science, 83:615-621.

Seker C, Karakaplan S (1999). Konya ovasında toprak özellikleri ile kırıma değerleri arasındaki ilișkiler. Turkish Journal of Agriculture And Forestry, 23:183-190.

Verheijen F, Jeffery S, Bastos AC, Van der Velde M, Diafas F (2010). Biochar application to soils. A critical scientific review of effects on soil properties, processes, and functions. EUR 24099 EN Office for the Official Publications of the European Communities, Luxembourg, P. 149.

Verhulst N, Govaert B, Verachtert E, CastellanosNavarrete A, Mezzalama M, Wall P, Chocobar A, Deckers J, Sayre KD (2010). Conservation agriculture, improving soil quality for sustainable production systems. In: Lal R, Stewart BA, editors. Advances in soil science: food security and soil quality. Boca Raton, FL: CRC Press, p. 137. C208.

Yamato M, Okimori Y, Wibowo IF, Anshori S, Ogawa M (2006). Effects of the application of charred bark of Acacia mangiumon the yield of maize, cowpea and peanut, and soil chemical properties in South Sumatra, Indonesia. Soil Science and Plant Nutrition, 52, 489-495. 